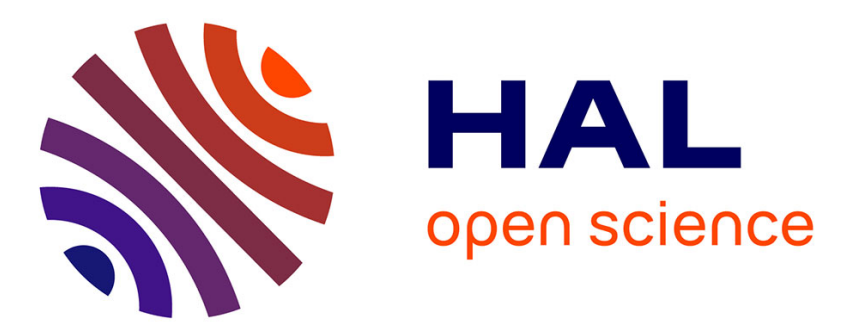

\title{
Comparative toxicity of [3] ferrocenophane and ferrocene moieties on breast cancer cells
}

\author{
Meral Görmen, Damian Plazuk, Pascal Pigeon, Elisabeth A. Hillard, \\ Marie-Aude Plamont, Siden Top, Anne Vessières, Gérard Jaouen
}

\section{To cite this version:}

Meral Görmen, Damian Plazuk, Pascal Pigeon, Elisabeth A. Hillard, Marie-Aude Plamont, et al.. Comparative toxicity of [3] ferrocenophane and ferrocene moieties on breast cancer cells. Tetrahedron Letters, 2010, 51 (1), pp.118-120. 10.1016/j.tetlet.2009.10.102 . hal-01230391

\section{HAL Id: hal-01230391 \\ https://hal.science/hal-01230391}

Submitted on 4 Jan 2017

HAL is a multi-disciplinary open access archive for the deposit and dissemination of scientific research documents, whether they are published or not. The documents may come from teaching and research institutions in France or abroad, or from public or private research centers.
L'archive ouverte pluridisciplinaire HAL, est destinée au dépôt et à la diffusion de documents scientifiques de niveau recherche, publiés ou non, émanant des établissements d'enseignement et de recherche français ou étrangers, des laboratoires publics ou privés. 


\section{Comparative toxicity of [3]ferrocenophane and ferrocene moieties on breast cancer cells}

Meral Gormen a, Damian Plazuk b, Pascal Pigeon a, Elizabeth A. Hillard a, Marie-Aude Plamont $^{\mathrm{a}}$, Siden Top ${ }^{\mathrm{a},{ }^{*}}$, Anne Vessières ${ }^{\mathrm{a}}$, Gérard Jaouen ${ }^{\mathrm{a},{ }^{*}}$

${ }^{a}$ Chimie ParisTech (Ecole Nationale Supérieure de Chimie de Paris), Laboratoire Charles Friedel, UMR CNRS 7223, 11 rue P. et M. Curie, 75231 Paris cedex 05, France

${ }^{\mathrm{b}}$ Department of Organic Chemistry, University of Łódz', Narutowicza 68, 90-136 Łódz', Poland

* Corresponding authors. Tel.: +33 (0) 1442766 99; fax: +33 (0) 143260061 (S.T.). E-mail address: sidentop@chimie-paristech.fr (S. Top).

\section{abstract}

Recent results suggest that [3]ferrocenophane may be an interesting motif in the development of cytotoxic anti-cancer agents. We here report the synthesis of three such compounds based on the 1-[(p-R-phenyl)-phenyl-methylidenyl)]-[3]ferrocenophane skeleton with $\mathrm{R}=\mathrm{OH}, \mathrm{NH}_{2}$ and $\mathrm{NHC}(\mathrm{O}) \mathrm{CH}_{3}$ substitution on one of the phenyl rings. Cytotoxicity studies show that these compounds are up to four times more powerful against hormone-independent breast cancer cells than their corresponding ferrocene analogs.

Keywords: Ferrocenophane ; Breast cancer ; Bioorganometallic ; Cytotoxicity

We have recently reported the synthesis and powerful antiproliferative effects on breast and prostate cancer cells of the diphenolic [3]ferrocenophane $\mathbf{1}^{1}$ This compound is considerably more potent than its non-cyclic analog $2,{ }^{2}$ with respective $\mathrm{IC}_{50}$ values of 0.09 and $0.6 \mu \mathrm{M}$ on hormone-independent MDA-MB-231 breast cancer cells. The point of attachment of the olefin was shown to be critical; when it was transposed from the 1 to the 2 
position of the bridge, the cytotoxic properties declined by an order of magnitude. This could be a result of breaking the conjugation between the ferrocene group and the phenol groups, as it has been shown that conjugated molecules in this class are more toxic than their unconjugated analogs. ${ }^{3}$ Ferrocene has been widely used in experimental medicinal chemistry, ${ }^{4-6}$ including a [3]ferrocenophane created from the coordination of the 1,1'bis(diphenylphosphino)ferrocene with gold, which was active against a panel of cancer cells. ${ }^{7}$

We have also examined the influence of changing the hydroxyl group for other functionalities, such as amines and halogens. ${ }^{8}$ The presence of a protic substituent is crucial for activity, and toxicity can be enhanced by replacement of the hydroxy group by $\mathrm{NH}_{2}$ or $\mathrm{NHC}(\mathrm{O}) \mathrm{CH}_{3} .{ }^{8}$ This is consistent with our proposed mechanism that quinoid compounds generated in situ are responsible for the toxicity of these compounds. ${ }^{9}$

We here show that, in this system, the [3]ferrocenophane motif is more toxic than the ferrocene moiety, via the comparison of the ferrocene compounds 3a-c (Fig. 1) with the analogous [3]ferrocephanes $\mathbf{4 a - c}$ on hormone-independent breast cancer cells (MDA-MB231).

Compounds 3a-c have been previously prepared by our group. ${ }^{8 a, 10} 1-[(p-R$-phenyl)phenyl-methylidenyl]-[3]ferrocenophane derivatives $\mathbf{4 a - b}$ were prepared in good yield via a McMurry cross-coupling reaction between [3]ferrocenophan-1-one ${ }^{11}$ and the appropriately substituted benzophenones, ${ }^{8 a}$ Scheme $1 .{ }^{12}$ Compound $4 \mathbf{c}$ was synthesized by the acetylation of the ferrocenophane aniline $\mathbf{4 a}$ using acetyl chloride in THF/pyridine. ${ }^{8,13}$ The $\mathrm{E}$ and $\mathrm{Z}$ isomers could not be separated by semi-preparative HPLC. 


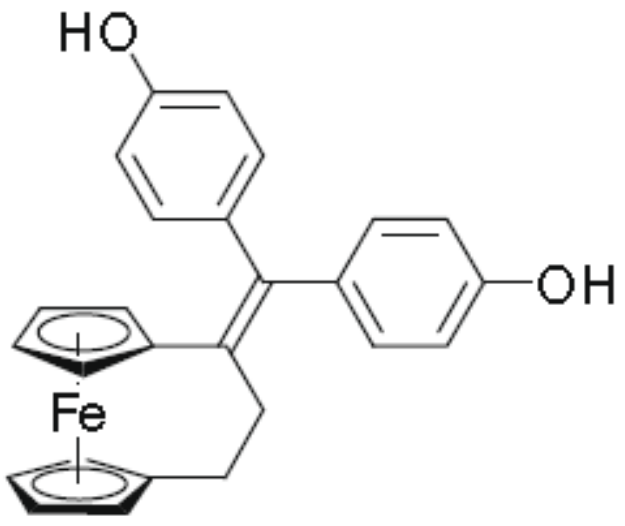

$1 ; 0.09 \mu \mathrm{M}$

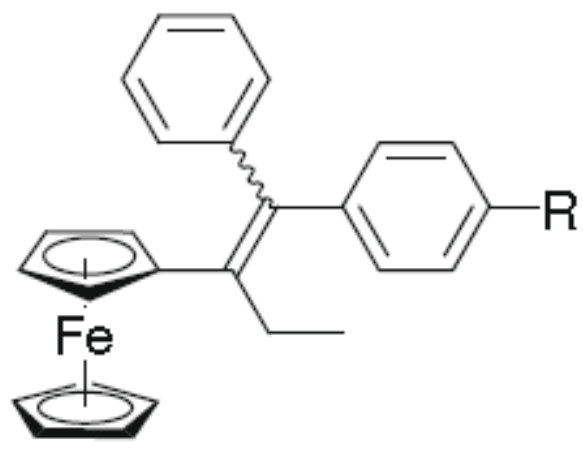

$3 a-c$

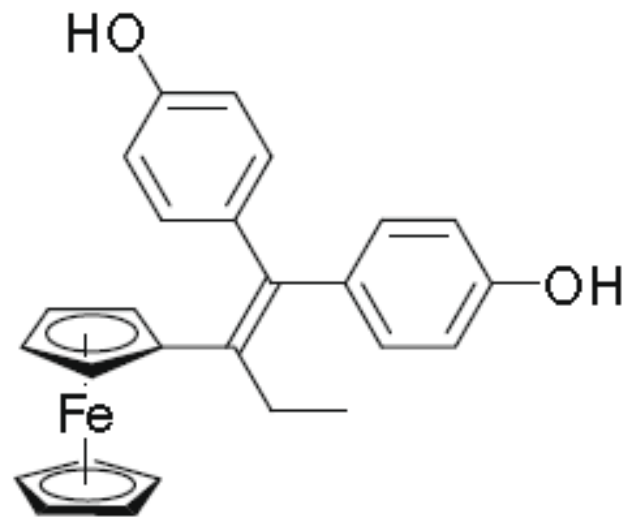

$2 ; 0.6 \mu \mathrm{M}$

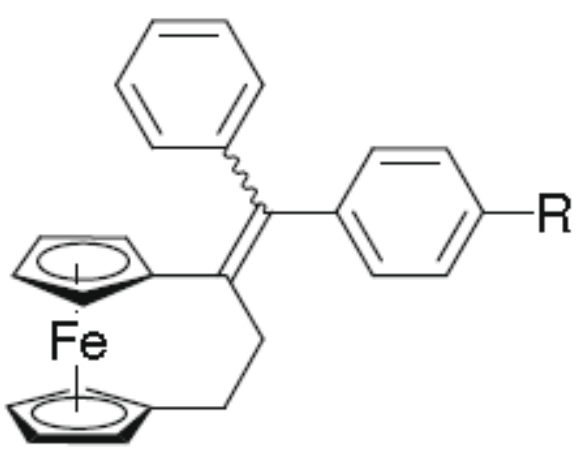

4a-c

Figure 1. Numbers following 1 and 2 are the $\mathrm{IC}_{50}$ values after 5 days of incubation with MDA-MB-231 hormone-independent breast cancer cells: (a) $\mathrm{OH}$; (b) $\mathrm{NH}_{2}$; and (c) $\mathrm{NHC}(\mathrm{O}) \mathrm{CH}_{3}$. 

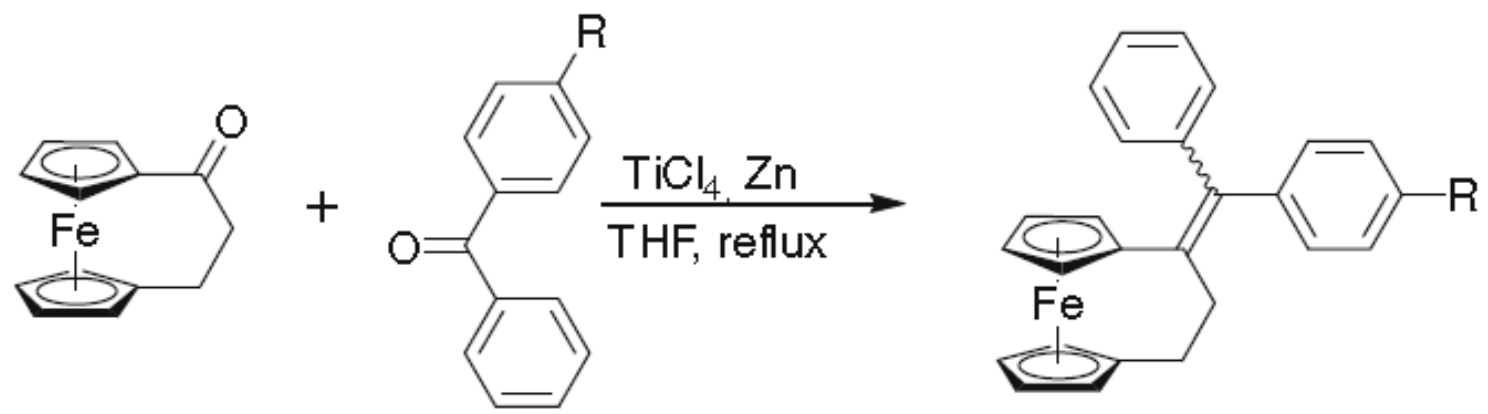

$(Z+E)-4 a: R=O H, 74 \%$
$(Z+E)-4 b: R=\mathrm{NH}_{2}, \quad 54 \%$

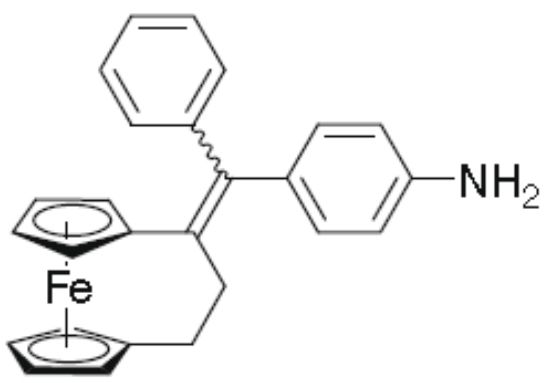

$4 a$

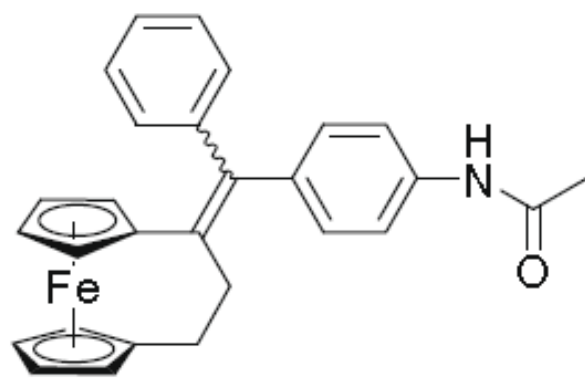

$(Z+E)-4 c, 75 \%$

Scheme 1.

Yellow blocks ${ }^{14}$ of $3 \mathbf{a}$ were obtained from a mixture of acetonitrile and water, and structural characterization by X-ray diffraction was carried out at $200 \mathrm{~K}$ using $\mathrm{Mo} / \mathrm{Ka}$ radiation. The ORTEP diagram is shown in Figure 2, with selected bond distances and angles. The two isomers $(E+Z)$ were co-crystallised in a 50:50 ratio, thus the hydroxyl groups have been modeled as disordered over the two phenyl rings, with an occupancy at each position of $50 \%$. The ferrocenyl moiety is oriented away from the phenyl group linked to the opposite carbon atom of the olefinic bond, presumably to minimize steric interactions. Similarly, there is a slight narrowing of the bond angle between the ethyl substituent and the ferrocene group connected to the same carbon atom of the double bond; and likewise for the two phenyl groups connected to the other carbon atom of the double bond. The ethylenic skeleton is moderately distorted with torsion angles of $11.2^{\circ}$ and $12.8^{\circ}$. The two phenyl moieties are tilted about $55^{\circ}$ with respect to the olefinic plane, while a corresponding twist angle of $37^{\circ}$ is observed for the ferrocene moiety. 


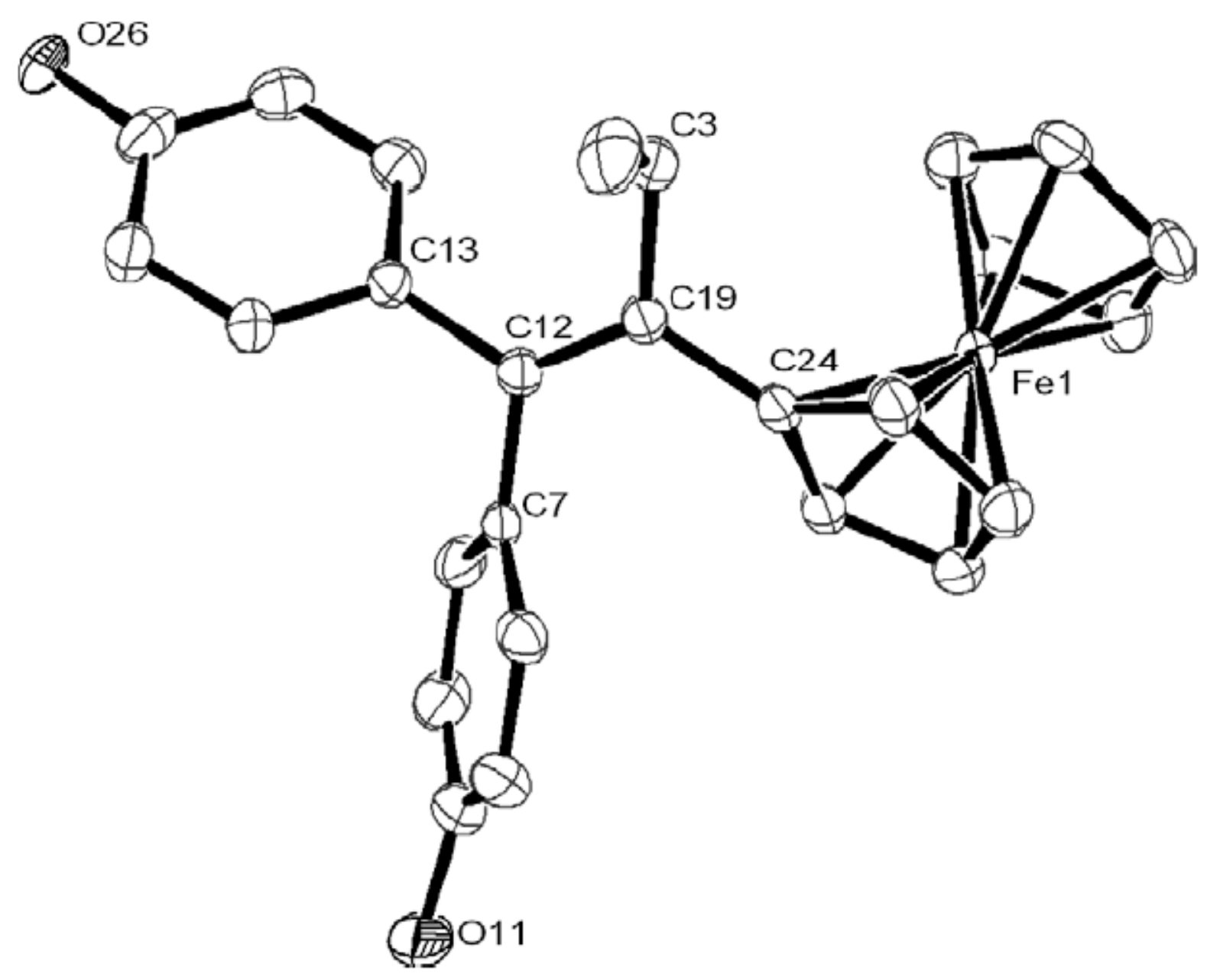

Figure 2. ORTEP diagram of 3a; thermal ellipsoids shown at 50\% probability level. Bond distances $(\AA)$ and angles $\left({ }^{\circ}\right)$ : Fe-C (mean) 2.065(2), C12-C19 1.371(2), C12-C13 1.507(2), C12-C7 1.505(2), C19-C24 1.490(3), C19-C3 1.533(3); C3-C19-C24 116.6(2), C13-C12C7 113.5(2), C7-C12-C19-C24 11.2(2), C3-C19-C12-C13 12.8(2).

Our previous studies of non-cyclic tetra-substituted ferrocenyl olefins show that parasubstitution of one or more of the phenyl rings with $\mathrm{OH}, \mathrm{NH}_{2}$, and $\mathrm{NHC}(\mathrm{O}) \mathrm{CH}_{3}$ yield the most toxic compounds. Thus we have tested the ferrocene and ferrocenophane derivatives with such substitution on the hormone-independent MDA-MB-231 breast cancer cell line, which does not respond to estrogenic or anti-estrogenic properties of molecules. Table 1 shows that $\mathrm{IC}_{50}$ values for the ferrocene-based compounds ranges from 1.1 to $0.65 \mu \mathrm{M}$. The ferrocenophane compounds are more toxic in each instance, with $\mathrm{IC}_{50}$ values ranging from 0.47 to $0.21 \mu \mathrm{M}$. Compounds $\mathbf{4 c}$ and $\mathbf{4 a}$ showed about a two-fold improvement, while $\mathbf{4 b}$, with $\mathrm{NH}_{2}$ substitution, was significantly more potent than its non-cyclic analog.

It should also be noted that the presence of two phenol groups versus one enhances the toxicity of compounds in both the ferrocene and [3]ferrocenophane series. In the ferrocene series the $\mathrm{IC}_{50}$ decreased from 1.13 to $0.6 \mu \mathrm{M}$ for the monophenol and diphenol; ${ }^{11}$ for the 
ferrocenophanes the corresponding decrease is from 0.47 to $0.09 \mu \mathrm{M} .^{1}$ Therefore, the next logical step is to prepare compounds with two identical or mixed substituents, particularly incorporating the $\mathrm{NH}_{2}$ group. With some nuances regarding the magnitude of the antiproliferative effect observed as a function of the substituents, $\mathrm{NH}_{2}, \mathrm{OH}$, and $\mathrm{NHC}(\mathrm{O}) \mathrm{CH}_{3}$, it is clear that the rigid [3]ferrocenophane permits an increase in the cytotoxic efficacy of the Fc-alkene-phenyl-R motif.

\section{Supplementary data}

Crystallographic data (excluding structure factors) for the structure in this paper have been deposited with the Cambridge Crystallographic Data Centre as supplementary publication no. 748334. Copies of the data can be obtained, free of charge, on application to CCDC, 12 Union Road, Cambridge CB2 1EZ, UK, (fax: $+44(0) 1223336033$ or email: deposit@ccdc.cam.ac.uk).

\section{Acknowledgements}

We thank P. Herson for X-ray structural characterization as well as the Agence Nationale de la Recherche (No. ANR-06-BLAN-0384-01, 'FerVect') financial support. M.G. acknowledges a fellowship from the Ministère des Affaires Etrangères.

\section{References and notes}

1. Plazuk, D.; Vessières, A.; Hillard, E. A.; Buriez, O.; Labbe, E.; Pigeon, P.; Plamont, M. A.; Amatore, C.; Zakrzewski, J.; Jaouen, G. J. Med. Chem. 2009, 52, 4964-4967.

2. Vessières, A.; Top, S.; Pigeon, P.; Hillard, E. A.; Boubeker, L.; Spera, D.; Jaouen, G. J. Med. Chem. 2005, 48, 3937-3940.

3. Hillard, E. A.; Vessières, A.; Le Bideau, F.; Plazuk, D.; Spera, D.; Huché, M.; Jaouen, G. ChemMedChem 2006, 1, 551-559.

4. $\quad$ Metzler-Nolte, N.; Salmain, M. In Ferrocenes Ligands Materials and Biomolecules; Stepnicka, P., Ed.; Wiley, 2008; pp 499-639.

5. $\quad$ Fouda, M. F. R.; Abd-Elzaher, M. M.; Abdelsamaia, R. A.; Labib, A. A. Appl. Organomet. Chem. 2007, 21, 613-625.

6. $\quad$ van Staveren, D. R.; Metzler-Nolte, N. Chem. Rev. 2004, 104, 5931-5985.

7. Viotte, M.; Gautheron, B.; Kubicki, M. M.; Mugnier, Y.; Parish, R. V. Inorg. Chem. 1995, 34, 34653473.

8. (a) Pigeon, P.; Top, S.; Zekri, O.; Hillard, E. A.; Vessières, A.; Plamont, M. A.; Buriez, O.; Labbe, E.; Huche, M.; Boutamine, S.; Amatore, C.; Jaouen, G. J. Organomet. Chem. 2009, 694, 895-901; (b) Zekri, O.; Hillard, E. A.; Top, S.; Vessières, A.; Pigeon, P.; Plamont, M.-A.; Huché, M.; Boutamine, S.; McGlinchey, M. J.; Müller-Bunz, H.; Jaouen, G. Dalton Trans. 2009, 4318-4328.

9. Hillard, E. A.; Pigeon, P.; Vessières, A.; Amatore, C.; Jaouen, G. Dalton Trans. 2007, 5073-5081.

10. Top, S.; Vessières, A.; Cabestaing, C.; Laios, I.; Leclercq, G.; Provot, C.; Jaouen, G. J. Organomet. Chem. 2001, 637, 500-506.

11. Turbitt, T. D.; Watts, W. E. J. Organomet. Chem. 1972, 46, 109-117.

12. Compound 4a: 74\% yield; 81/19 isomer ratio; ${ }^{1} \mathrm{H}$ NMR (300 MHz, acetone- $\left.d_{6}\right)$ : $\delta$ 2.31-2.38 (m, $2 \mathrm{H}$, $\left.\mathrm{CH}_{2}\right), 2.64-2.67$ and 2.72-2.76 (m, $\left.2 \mathrm{H}, \mathrm{CH}_{2}\right), 3.93\left(\mathrm{t}, \mathrm{J}=1.9 \mathrm{~Hz}, 2 \mathrm{H}, \mathrm{C}_{5} \mathrm{H}_{4}\right), 3.98(\mathrm{t}, J=1.9 \mathrm{~Hz}, 2 \mathrm{H}$, $\left.\mathrm{C}_{5} \mathrm{H}_{4}\right), 3.95$ and $4.01\left(\mathrm{t}, J=1.9 \mathrm{~Hz}, 2 \mathrm{H}, \mathrm{C}_{5} \mathrm{H}_{4}\right), 4.25\left(\mathrm{t}, J=1.9 \mathrm{~Hz}, 2 \mathrm{H}, \mathrm{C}_{5} \mathrm{H}_{4}\right), 6.55(\mathrm{~d}, J=8.5 \mathrm{~Hz}, 2 \mathrm{H}$, $\left.\mathrm{C}_{6} \mathrm{H}_{4}\right), 6.84\left(\mathrm{~d}, J=8.5 \mathrm{~Hz}, 2 \mathrm{H}, \mathrm{C}_{6} \mathrm{H}_{4}\right), 7.01-7.39\left(\mathrm{~m}, 5 \mathrm{H}, \mathrm{C}_{6} \mathrm{H}_{5}\right), 8.13$ and $8.32(\mathrm{~s}, 1 \mathrm{H}, \mathrm{OH}) .{ }^{13} \mathrm{C}$ NMR $\left(75.4 \mathrm{MHz}\right.$, acetone- $\left.d_{6}\right): \delta 29.2\left(\mathrm{CH}_{2}\right), 41.3\left(\mathrm{CH}_{2}\right), 68.9\left(2 \mathrm{CH} \mathrm{C}_{5} \mathrm{H}_{4}\right), 69.2$ and $69.3\left(2 \mathrm{CH} \mathrm{C}_{5} \mathrm{H}_{4}\right), 70.9$ $\left(2 \mathrm{CH} \mathrm{C}_{5} \mathrm{H}_{4}\right), 71.0\left(2 \mathrm{CH} \mathrm{C}_{5} \mathrm{H}_{4}\right), 84.5\left(\mathrm{C}_{\mathrm{ip}}\right), 87.5\left(\mathrm{C}_{\mathrm{ip}}\right), 114.2$ and $115.0\left(2 \mathrm{CH}_{\text {arom }}\right), 127.3\left(\mathrm{CH}_{\text {arom }}\right)$, 
128.0 and $128.9\left(2 \mathrm{CH}_{\text {arom }}\right), 130.0$ and $131.2\left(2 \mathrm{CH}_{\text {arom }}\right), 131.2$ and $132.3\left(2 \mathrm{CH}_{\text {arom }}\right), 134.3(\mathrm{C}), 135.4$ (C), 141.6 (C), 145.0 (C), 153.7 (C). IR (KBr, $\left.\mathrm{cm}^{-1}\right)$ : 2922.9, 2842.1, 1608.3, 1509.2, 1439.2, 1425.9,

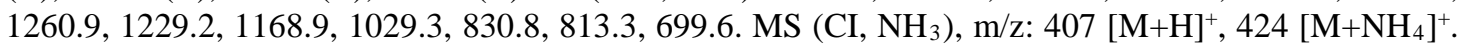
Anal. Calcd for $\mathrm{C}_{26} \mathrm{H}_{22} \mathrm{FeO} .1 / 4 \mathrm{H}_{2} \mathrm{O}$ : C, 76.01; H, 5.51. Found: C, 75.71; H, 5.55. Compound 4b: $54 \%$ yield; 87/13 isomer ratio; ${ }^{1} \mathrm{H}$ NMR $\left(300 \mathrm{MHz} \mathrm{CDCl}_{3}\right): \delta 1.48-2.35\left(\mathrm{~m}, 2 \mathrm{H}, \mathrm{NH}_{2}\right), 2.19-2.35(\mathrm{~m}, 2 \mathrm{H}$, $\mathrm{CH}_{2}$ ), 2.49-2.61 and 2.62-2.70 (m, 2H, $\left.\mathrm{CH}_{2}\right), 3.91\left(\mathrm{~s}, 2 \mathrm{H}, \mathrm{C}_{5} \mathrm{H}_{4}\right), 3.93\left(\mathrm{~s}, 2 \mathrm{H}, \mathrm{C}_{5} \mathrm{H}_{4}\right), 3.97(\mathrm{~s}, 2 \mathrm{H}$, $\left.\mathrm{C}_{5} \mathrm{H}_{4}\right), 4.14\left(\mathrm{~s}, 2 \mathrm{H}, \mathrm{C}_{5} \mathrm{H}_{4}\right), 6.34$ and $6.60\left(\mathrm{~d}, J=8.5 \mathrm{~Hz}, 2 \mathrm{H}, \mathrm{C}_{6} \mathrm{H}_{4}\right), 6.76$ and $6.93(\mathrm{~d}, J=8.5 \mathrm{~Hz}, 2 \mathrm{H}$, $\left.\mathrm{C}_{6} \mathrm{H}_{4}\right)$, 6.97-7.37 (m, 5H, $\left.\mathrm{C}_{6} \mathrm{H}_{5}\right) .{ }^{13} \mathrm{C}$ NMR (75.4 MHz, acetone- $\left.d_{6}\right): \delta 29.3\left(\mathrm{CH}_{2}\right), 41.2$ and 41.4 $\left(\mathrm{CH}_{2}\right), 68.9\left(2 \mathrm{CH} \mathrm{C} \mathrm{C}_{4}\right), 69.2$ and $69.3\left(2 \mathrm{CH} \mathrm{C} \mathrm{C}_{4}\right), 71.0\left(2 \times 2 \mathrm{CH} \mathrm{C} \mathrm{H}_{4}\right), 84.3\left(\mathrm{C}_{\mathrm{ip}}\right), 87.5\left(\mathrm{C}_{\mathrm{ip}}\right)$, 114.0 and $114.7\left(2 \mathrm{CH}_{\text {arom }}\right), 127.3$ and $127.5\left(\mathrm{CH}_{\text {arom }}\right), 128.9$ and $129.1\left(2 \mathrm{CH}_{\text {arom }}\right), 130.0$ and 130.1 (2 $\mathrm{CH}_{\text {arom }}$ ), 131.6 and 132.1 (2 $\left.\mathrm{CH}_{\text {arom }}\right), 133.0$ (C), 135.2 (C), 138.6 (C), 144.7 (C), 147.5 (C). IR (KBr, v $\left.\mathrm{cm}^{-1}\right)$ : 3454, $3375\left(\mathrm{NH}_{2}\right)$, 3083, 2924, $2846\left(\mathrm{CH}_{2}\right)$. MS (EI, $\left.70 \mathrm{eV}\right) \mathrm{m} / \mathrm{z} 405[\mathrm{M}]^{+}$, 326. Anal. Calcd for $\mathrm{C}_{26} \mathrm{H}_{23} \mathrm{FeN}$ : C, 77.04; H, 5.71; N, 3.45. Found: C, 76.79; H, 5.79; N, 3.52.

13. Compound 4c: 75\% yield; 80/20 isomer ratio; ${ }^{1} \mathrm{H}$ NMR (300 MHz, $\mathrm{CDCl}_{3}$ ): $\delta 2.11\left(\mathrm{~s}, 3 \mathrm{H}, \mathrm{CH}_{3}\right), 2.23-$ $2.37\left(\mathrm{~m}, 2 \mathrm{H}, \mathrm{CH}_{2}\right), 2.55-2.69\left(\mathrm{~m}, 2 \mathrm{H}, \mathrm{CH}_{2}\right), 4.03\left(\mathrm{~s}, 4 \mathrm{H}, \mathrm{C}_{5} \mathrm{H}_{4}\right), 4.08\left(\mathrm{~s}, 2 \mathrm{H}, \mathrm{C}_{5} \mathrm{H}_{4}\right), 4.26(\mathrm{~s}, 2 \mathrm{H}$, $\left.\mathrm{C}_{5} \mathrm{H}_{4}\right), 6.94-7.48\left(\mathrm{~m}, 9 \mathrm{H}, \mathrm{C}_{6} \mathrm{H}_{4}\right.$ and $\left.\mathrm{C}_{6} \mathrm{H}_{5}\right) .{ }^{13} \mathrm{C} \mathrm{NMR}\left(75.4 \mathrm{MHz}, \mathrm{CDCl}_{3}\right): \delta 24.6\left(\mathrm{CH}_{3}\right), 28.7\left(\mathrm{CH}_{2}\right)$, $40.9\left(\mathrm{CH}_{2}\right), 68.7\left(2 \mathrm{CH} \mathrm{C}_{5} \mathrm{H}_{4}\right), 69.2\left(2 \mathrm{CH} \mathrm{C}_{5} \mathrm{H}_{4}\right), 70.3\left(2 \mathrm{CH} \mathrm{C} \mathrm{H}_{4}\right), 70.4\left(2 \mathrm{CH} \mathrm{C}_{5} \mathrm{H}_{4}\right), 83.6\left(\mathrm{C}_{\mathrm{ip}}\right), 86.8$ $\left(\mathrm{C}_{\text {ip }}\right), 118.6$ and $119.5\left(2 \mathrm{CH}_{\text {arom }}\right), 126.7\left(\mathrm{CH}_{\text {arom }}\right), 127.3$ and $128.2\left(2 \mathrm{CH}_{\text {arom }}\right), 129.3$ and 129.9 (2 $\left.\mathrm{CH}_{\text {arom }}\right), 130.5$ and $131.1\left(2 \mathrm{CH}_{\text {arom }}\right), 134.7$ (C), 135.8 (C), 139.2 (C), 140.2 (C), 143.4 (C), 168.0 (CO). IR (KBr, $\left.v \mathrm{~cm}^{-1}\right)$ : 2925, $2847\left(\mathrm{CH}_{2}\right), 1665$ (CO). MS (EI, $\left.70 \mathrm{eV}\right) \mathrm{m} / \mathrm{z}: 447[\mathrm{M}]^{+}, 368,43$ $\left[\mathrm{CH}_{3} \mathrm{CO}\right]^{+}$; HRMS (ESI, $\mathrm{C}_{28} \mathrm{H}_{25} \mathrm{FeNO}$ : [M] ${ }^{+}$): calcd: 447.1286, found: 447.1280. Anal. Calcd for $\mathrm{C}_{28} \mathrm{H}_{25} \mathrm{FeNO} .3 / 4 \mathrm{H}_{2} \mathrm{O}$ : C, 72.97; H, 5.79. Found: C, 72.74; H, 5.74.

14. Intensity data ( $\varphi$ and scans) were collected with a Enraf-Nonius Kappa-CCD diffractometer equipped with a CCD two-dimensional detector. Data reduction was performed with DENZO/SCALEPACK. Data were corrected for Lorentz and polarization effects, and an semi-empirical absorption correction based on symmetry equivalent reflections was applied using SADABS. Lattice parameters were obtained from least-squares analysis of 100 reflections. The structures were solved by direct methods and refined by full matrix least squares, based on $\mathrm{F}^{2}$, using the Crystals software package. All nonhydrogen atoms were refined with anisotropic displacement parameters. All hydrogen atoms were located with geometrical restraints in riding mode. $\mathrm{C}_{26} \mathrm{H}_{23} \mathrm{FeO} ; 407.32 \mathrm{~g} \mathrm{~mol}^{-1}$; triclinic; $\mathrm{P} 1 ; a=$ 8.9714(8) $\AA ; b=10.4256(7) \AA ; c=12.085(1) \AA ; \alpha=71.756(7)^{\circ} ; \beta=71.370(9)^{\circ} ; \gamma=89.005(7)^{\circ} ; \mathrm{V}=$ 1012.9(2) $\AA^{3} ; \mathrm{Z}=2 ; \mathrm{D}_{\text {calcd }}=1.335 \mathrm{~g} \mathrm{~cm}^{-3} ; \mu=0.757 \mathrm{~mm}^{-1} ; \mathrm{F}\left(\begin{array}{lll}0 & 0 & 0\end{array}\right)=426$; data/restraints/parameters $=$ $7006 / 0 / 263 ; \mathrm{R} / \mathrm{R}_{\mathrm{w}}$ (all data) $=0.0707 / 0.1101$. 